\title{
A MEDIATED MODEL OF RELATIONSHIP QUALITY FACTORS AFFECTING BEHAVIOURAL INTENTION AT A LUXURY MOTOR VEHICLE DEALERSHIP
}

\author{
Estelle van Tonder, Daniël Johannes Petzer and Karlien van Zyl
}

Prof E van Tonder

School of Business Management

North-West University

Private Bag X6001

Potchefstroom

2520

Tel: 0182852204

Email: estellevantonder4@gmail.com

Prof DJ Petzer

Gordon Institute of Business Science

University of Pretoria

PO Box 787602

Sandton

2146

Tel: 0117714242

Email: petzerd@gibs.co.za

Ms K van Zyl

School of Business Management

North-West University

Private Bag X6001

Potchefstroom

2520

Tel: 115405000

Email: karlien@porsche.co.za 


\section{Research funding:}

This work is based on research supported in part by the National Research Foundation of South Africa (Grant Number: 104662).

\section{Disclaimer:}

Any opinion, finding and conclusion or recommendation expressed in this material is that of the authors and the National Research Foundation of South Africa does not accept any liability in this regard.

\section{ABSTRACT}

Purpose - The aim of this study is to determine whether customer satisfaction, trust and commitment as relationship quality factors can be valuable to a luxury motor vehicle dealership in generating favourable behavioural intentions concerning post-purchase service and repair offerings.

Design/methodology/approach - A descriptive research design was followed and selfadministered questionnaires were fielded among customers of the luxury motor vehicle dealership. A total of 301 questionnaires were returned and the interrelationships between the constructs were examined using structural equation modelling.

Findings - It was discovered that customers who trust the dealership may be more committed, and commitment may strengthen the relationship between customer satisfaction and a favourable behavioural intention towards the dealership.

Research implications - The findings of the study add to the developing body of empirical literature on relationship quality and behavioural intention.

Practical implications - The study indicates how relationship quality factors can influence behavioural intentions of customers, assist in building long-term relationships with customers, and retain current customers where post-purchase service and repairs of luxury goods are concerned.

Originality/value - The study provides an emerging market perspective of the interrelationships between relationship quality factors affecting behavioural intention regarding service and repairs of luxury goods.

Key words behavioural intention, commitment, customer satisfaction, trust

Paper type Research paper 


\section{INTRODUCTION}

Globally, the desire for, and consumption of, luxury brands are no longer the privilege of just a wealthy few (Kapferer and Valette-Florence, 2016). The luxury sector is experiencing vibrant growth worldwide and the sector is finding new markets where they did not exist before (Chandon, Laurent and Valette-Florence, 2015). Competition between organisations in the luxury sector is also increasing with the introduction of new brands (Choo, Moon, Kim and Yoon, 2012) and this is compounded by the fact that customers often trade-up and readily switch between luxury brands (Choo et al., 2012). Customers' needs are everchanging and in a highly competitive business environment it is easy to forfeit customers to competitors, resulting in financial losses for organisations (Giovanis, Athanasopoulou and Tsoukatos, 2015).

Similar trends have also been noted in the South African luxury motor vehicle segment. The luxury motor vehicle industry in South Africa is growing along with the increasing number of wealthy individuals produced on an annual basis (Fin24, 2016). According to recent statistics provided by the National Association of Automobile Manufacturers of South Africa, the BMW Group, for example, sold 1165 cars in July 2016, followed by Jaguar (121), Porsche (99), Ferrari (16) and Maserati (5) (NAAMSA, 2016). Luxury cars are sought by the wealthy in a quest for status. However, there is fierce competition as many international luxury brands are fighting for the South African luxury motor vehicle market, and customers can choose from a wide range of luxury motor vehicles, including, for example, Aston Martin, Ferrari, Lamborghini, McLaren or Porsche (Fin24, 2016).

To succeed in this highly competitive environment, it may be beneficial for luxury motor vehicle brands to focus more on their post-purchase service offering and to establish longterm relationships with their customers. It has been stated that, compared to new vehicle sales, gross profit margins are higher in the post-purchase service and repairs department (Henry, 2012). It is further believed that revenue in a retail environment, as with postpurchase service and repairs at a luxury motor vehicle dealership, is primarily dependent on customers who conduct business with the organisation over a long term (Ou, Shih, Chen and Wang, 2011). Therefore, building long-term relationships with customers through relationship marketing is of paramount importance for an organisation to survive and prosper (Khojastehpour and Johns, 2014). For organisations to make the most of and maintain profitable relationships with customers, they need to understand the vibrant nature of such relationships (Storbacka, Strandvik and Grönroos, 1994), and the strategies required to establish quality relationships. Within the relationship marketing domain, relationship quality assists organisations in understanding relationships with customers and is considered an indicator of the extent to which organisations are able to satisfy the needs of their customers 
(Ou et al., 2011). Relationship quality is furthermore multidimensional (Giovanis et al., 2015) and it is believed that trust, commitment and customer satisfaction are fundamental constituents of relationship quality (Grönroos, 2001; Hennig-Thurau, 2000; Hennig-Thurau, Gwinner and Gremler, 2002).

However, extant literature provides a limited understanding of the interrelationships between relationship quality and its related constructs, of which behaviour intention could be one (Vieira, 2013). The interrelationship between customer satisfaction, trust and commitment, and behavioural intention has not yet been fully investigated within the South African luxury motor vehicle industry. Knowledge of these relationships can aid in identifying weaknesses in a luxury motor vehicle dealership's customer service policies, specifically regarding postpurchase service and repairs. It can also provide a better understanding of how increased customer satisfaction, trust and commitment can positively influence the behavioural intention of a luxury motor vehicle dealership's customers and thereby provide a competitive advantage in a highly volatile luxury motor vehicle market. Therefore, the objective of the study is to uncover whether customer satisfaction, trust and commitment as relationship quality factors, can be valuable to a luxury motor vehicle dealership in generating favourable behavioural intention. A theoretical framework is presented, followed by the theoretical model suggested for the study. This is followed by the research design and method, data analysis and findings, and the research implications, limitations and directions for further research.

The theoretical contribution of the study is vested in uncovering the interrelationships between the factors of relationship quality and behavioural intention at a luxury motor dealership concerning its post-purchase service and repairs to customers' luxury motor vehicles. More specifically, the mediating effect of commitment on the relationships between customer satisfaction, trust and behavioural intention is uncovered. When considering the proposed contribution of the study from a managerial perspective, the empirical results of the study indicate how relationship quality factors can be utilised by a luxury motor dealership to influence the behavioural intentions of its customers to assist the dealership in building longterm relationships with its customers and to retain its current customers where postpurchase service and repairs are concerned.

\section{THEORETICAL FRAMEWORK}

Figure 1 provides the theoretical model for this study. The model illustrates the interrelationships between the relationship quality factors (namely customer satisfaction, trust and commitment) in relation to behavioural intention. Prior to presenting the hypotheses 
and proposed theoretical model, the study is theoretically framed by providing insight into relationship marketing, relationship quality and its factors followed by an overview of behavioural intention as the key outcome variable in the proposed theoretical model.

\subsection{Relationship marketing, relationship quality and relationship quality constructs}

The foundation of any marketing system is lodged in the relationship between two parties: the organisation that produces products and services, and the customer who consumes the products and services (Shaw, 2014). Building relationships between organisations and customers is a holistic approach and is often referred to as relationship marketing (Herington, Johnson and Scott, 2006; Stavros and Westberg, 2009). Relationship marketing theory implies that customers will enter relationships with organisations when they expect to benefit from the exchanges that take place as a result of the relationship (Hunt, Arnett and Madhavaram, 2006). These benefits may include the social bonds that are established, the extraordinary service that is delivered and the trust that is fostered (Grönroos, 2001). According to Hunt et al. (2006), an organisation's relationship marketing-based strategy will only be successful if the organisation focuses on fostering the relational factors viewed as measures of relationship marketing success - namely, trust and commitment as well as customer satisfaction. In the early 1990s, Storbacka et al. (1994) argued that customer relationships should be viewed over a long term with a dynamic relationship quality perspective in mind.

Relationship quality is viewed as a multidimensional construct (Giovanis et al., 2015) that represents the state of the relationships between customers and organisations, which typically leads to long-term relationships between the parties concerned and results in the subsequent retention of customers (Grönroos, 2001; Hennig-Thurau, 2000; Hennig-Thurau et al., 2002). Moreover, Crosby, Evans and Cowles (1990) view the construct as a reflection of the extent to which organisations satisfy the needs of a customer. Ural (2009) refers to it as the resilience of the relationship between customers and organisations. Relationship quality is finally considered as a foundation of organisational competitiveness (Vieira, 2013).

According to Athanasopoulou (2009), several dimensions or factors of relationship quality have been identified without any consensus on the factors that constitute relationship quality. However, three key factors of relationship quality are typically acknowledged: customer satisfaction, trust and commitment (De Wulf, Odekerken-Schröder and lacobucci, 2001; De Wulf, Odekerken-Schröder and Van Kenhove, 2003; Giovanis et al., 2015; Lang and Colgate, 2003; Lin and Ding, 2005; Macintosh, 2007; Moliner, Sánchez, Rodríguez and 
Callarisa, 2007a; Roberts, Varki, and Brodie, 2003). For the purpose of this study, these three factors are considered.

Customer satisfaction leads to significant economic benefits for organisations, and by understanding customer satisfaction they can bring about what is considered a "strategic necessity" (Jaiswal and Niraj, 2011; Vranesevic, Vignali and Vignali, 2002). Satisfying customers is becoming more difficult as customers not only expect satisfaction based on functional benefits, but also seek satisfaction through unique experiences offered by organisations (McCole, 2004). In a services context, Zeithaml and Bitner (2000) recognise that customer satisfaction is the result of customers' comparing the expectations of a service experience with the perceptions of the actual service received from organisations. If their expectations match their perceptions, they are satisfied; if they do not, they are dissatisfied (Zeithaml and Bitner, 2000). This definition is typical of the disconfirmation approaches to both customer satisfaction and service quality that profess that customer satisfaction/dissatisfaction results from the difference between customer expectations and perceptions (Martin, O'Neill, Hubbard and Palmer, 2008). Martin et al. (2008) further state that customer satisfaction involves a cognitive and an affective component that impact the formation of satisfaction. This is aligned with the definition by Storbacka et al. (1994:25), who describe customer satisfaction "as customers' cognitive and affective evaluation based on personal experience across all service episodes within the relationship". Customer satisfaction leads to a change in attitude due to customers' experiences of a product or service (McCollough, Berry and Yadav, 2000). In addition to this, a distinction is drawn in literature between satisfaction that is transaction-based versus satisfaction that is more enduring in nature and not solely reliant on a single experience (Hess and Story, 2005).

In this study, both the cognitive and affective components of customer satisfaction are considered and measured as a summative concept of the complete experience of consuming the service offered, as contended by Johnson and Fornell (1991). In addition, the study also considers enduring satisfaction rather than satisfaction that is transaction-based.

Trust refers to the anticipation by a party that the other party in the relationship will act in an expected manner (Grönroos, 2001). Trust is also regarded as the foundation of the relationship between customers and organisations (Hess and Story, 2005). It is vested in certainty and integrity since the parties involved in the relationship intend to behave positively towards each another, focusing on maintaining the relationship they have invested in (Moreira and Silva, 2015). Trust is also important in a services context as services are intangible and "trust" is often used as a tool to market the organisation's services to a customer (Berry, 1995). Although many dimensions of trust have been identified, several 
authors agree that trust comprises two key dimensions: credibility and benevolence trust (Casielles, Álvarez and Martín, 2005; Kansperger and Kunz, 2010; Moliner, Sánchez, Rodríguez and Callarisa, 2007b). Credibility trust involves the notion that the party concerned is able to perform as required by the other party, while benevolence trust refers to the notion that the one party takes the other party's interest to heart (Anderson and Narus, 1990). In this study, both credibility and benevolence trust is considered.

Commitment is another important aspect when developing relationships between customers and organisations (Fullerton, 2005) and is conceptualised as customers' and organisations' "intentions to act and their attitude towards interacting with each other" (Storbacka et al., 1994:25) over an extended period of time (Farrelly and Quester, 2005). Morgan and Hunt (1994) view commitment as a belief held by customers and/or organisations that the relationship between the parties concerned is so important that the parties concerned work to maintain the relationship. Hess and Story (2005:312) add that commitment involves a customer's "ultimate relationship disposition" encapsulating their "beliefs, attitudes and behaviors". Considering this definition, it is only logical that commitment is considered a multidimensional construct including normative, affective and calculative commitment (Hess and Story, 2005; Vesel and Zabkar, 2010).

According to Jones, Fox, Taylor and Fabrigar (2010), normative commitment refers to customers acting a certain way towards an organisation because they believe they are obliged to do so or that it is the moral thing to do. Affective commitment refers to customers acting a certain way towards an organisation because of their feelings and emotions towards the organisation (Jones et al., 2010). Finally, calculative commitment refers to customers acting a certain way towards an organisation because of a rational and economic reason (Jones et al., 2010). For the purpose of the study, normative, affective and calculative commitment as a summative concept of a customer's commitment to an organisation, are considered.

\subsection{Behavioural intention}

Behavioural intention, as a construct that is both intricate and comprehensive (Cronin, Brady and Hult, 2000), can be associated with the theory of reasoned action and refers to the probability that a customer will behave in a particular manner in future (Southey, 2011). This is valuable in estimating the future consumption of customers and those that receive wordof-mouth communications from these customers (Jani and Han 2011). Furthermore, behavioural intention is considered essential to organisations that wish to maintain 
relationships with customers over a long term (Amin and Nasharuddin, 2013). Parasuraman, Berry and Zeithaml (1994), widely credited for putting forward the most comprehensive taxonomy of behavioural intention, argue that behavioural intention comprises of four categories including complaint behaviour, word-of-mouth communication, repurchase intention and price sensitivity. In this particular study, behavioural intention is measured with items reflecting on customer's intentions with respect to word-of-mouth communication, repurchase intentions and price sensitivity. Customers' intention with respect to complaint behaviour was not measured as the study did not presuppose a service failure as basis of measuring behavioural intention.

\section{THEORETICAL MODEL DEVELOPMENT}

Previous studies in the field of relationship marketing were considered in the development of the theoretical model for this study. The proposed interrelationships between the three relationship quality factors and behavioural intention are subsequently considered.

\subsection{The relationships between customer satisfaction, commitment and behavioural intention}

It is evident from several studies conducted in different service, retail and luxury brand contexts that customer satisfaction has a significant positive relationship with behavioural intention (Amin and Nasharuddin, 2013; Cronin et al., 2000; Liang and Zhang, 2012; Martin et al., 2008; Qin and Prybutok, 2009). Similarly, the relationship between customer satisfaction and commitment has also been well-established (Dimitriades, 2006; Hess and Story, 2006; Jani and Han 2011; Johnson, Sivadas and Garbarino, 2008; Ou et al., 2011). Commitment has also been found to be significantly related to behaviour intention and, with respect to its different categories as proposed by Parasuraman et al. (1994), to different service, retail and luxury brand contexts (Fullerton, 2014; Jani and Han, 2011; Liang and Wang, 2007; Moreira and Silva, 2015; Shukla, Banerjee and Singh, 2016). Therefore, two relationship quality factors - customer satisfaction and commitment - are hypothesised to have significant relationships with each other and the behavioural intention of customers when post-purchase service and repairs at a luxury motor vehicle dealership are considered. Based on these findings, the following hypotheses are formulated for the study:

$\mathrm{H}_{1}$ : Customer satisfaction significantly and positively influences behavioural intention in favour of a luxury motor vehicle dealership.

$\mathrm{H}_{2}$ : $\quad$ Customer satisfaction significantly and positively influences commitment towards a 
luxury motor vehicle dealership.

$\mathrm{H}_{3}$ : $\quad$ Commitment significantly and positively influences behavioural intention in favour of a luxury motor vehicle dealership.

In addition to these three hypotheses, the following hypothesis has been formulated to determine whether the relationship quality factor, commitment, mediates the relationship between customer satisfaction and behavioural intention concerning post-purchase service and repairs at a luxury motor vehicle dealership:

$\mathrm{H}_{4}$ : $\quad$ Customer satisfaction has a significant positive indirect effect on behavioural intention in favour of a luxury motor vehicle dealership as mediated by commitment towards the dealership.

\subsection{The relationships between trust, commitment and behavioural intention}

The studies conducted in different service-, retail- and luxury brand-related contexts as well as online environments (Becerra and Korgoankar, 2011; Forgas-Coll, Palau-Saumell, Sánchez-García and Caplliure-Giner, 2014; Liang and Wang, 2007; Limbu, Wolf and Lunsford, 2012) bear testament to the fact that trust has a significant positive relationship with customers' behavioural intentions. It was also found that trust holds a significant relationship with commitment in various service-related contexts as well as in a luxury brand context (Moreira and Silva, 2015; Ou et al., 2011; Sumaedi, Juniarti and Bakti, 2015; Shukla et al., 2016). Therefore, the two relationship quality factors, trust and commitment, are hypothesised to have significant relationships with each other while trust also has a significant relationship with the behavioural intention of customers in relation to postpurchase service and repairs at a luxury motor vehicle dealership. Based on these findings the following hypotheses are formulated for the study:

$\mathrm{H}_{5}$ : $\quad$ Trust significantly and positively influences behavioural intention in favour of a luxury motor vehicle dealership.

$\mathrm{H}_{6}$ : $\quad$ Trust significantly and positively influences commitment towards a luxury motor vehicle dealership.

Additionally, the following hypothesis has been formulated to determine whether the relationship quality factor, commitment, has a mediating effect on the relationship between trust and behavioural intention concerning post-purchase service and repairs at a luxury motor vehicle dealership: 
$\mathrm{H}_{7}$ : Trust has a significant positive indirect effect on behavioural intention in favour of a luxury motor vehicle dealership as mediated by commitment towards the dealership.

Figure 1 provides a graphical illustration of the hypothesised relationships that were formulated for the empirical investigation.

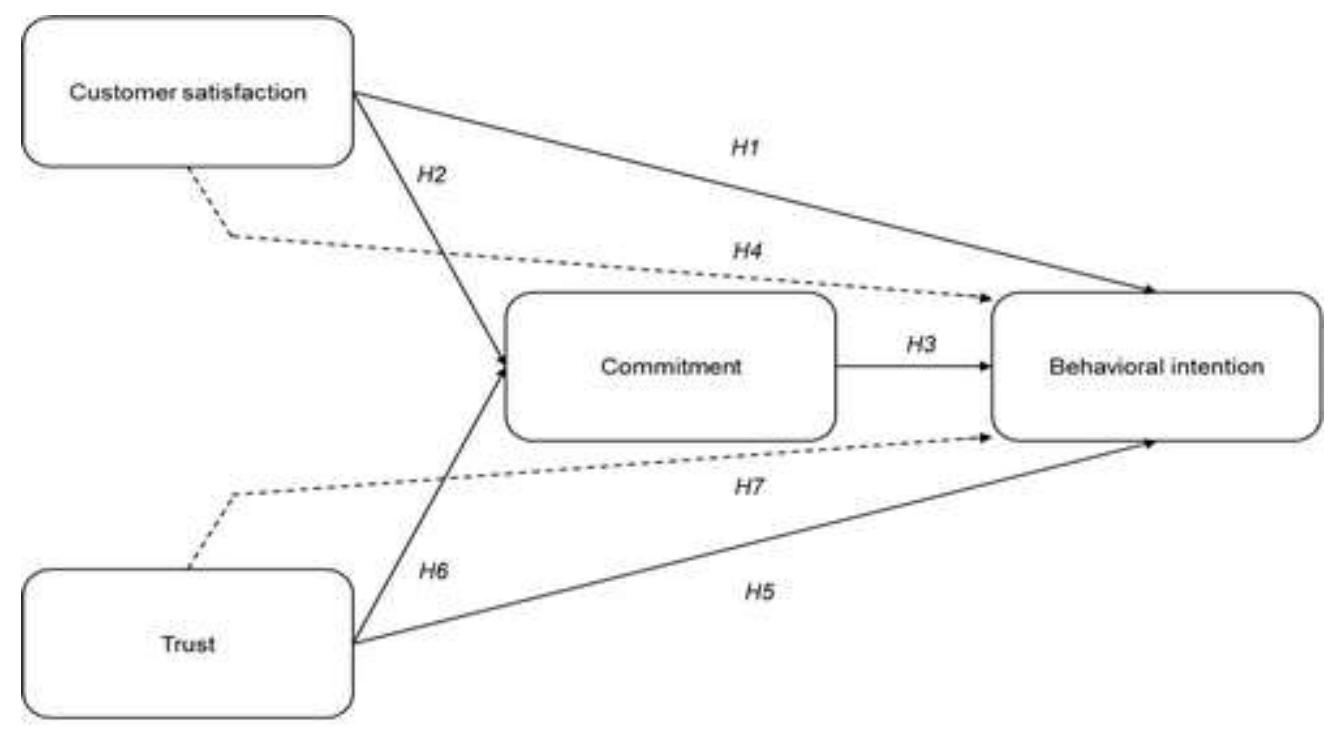

Source: Researchers' own construct

Figure 1. Proposed theoretical model

\section{RESEARCH DESIGN AND METHOD}

The research design was descriptive and quantitative in nature. The population was defined as individuals who had their motor vehicles serviced or repaired at the luxury motor vehicle dealership in Gauteng within the past 24 months. The study focused on a single luxury motor vehicle dealership in Gauteng. In the past three years, this specific dealership has shown admirable growth in sales despite servicing a niche market and possessing limited marketing resources (Roussouw, 2013). The results of this study may enable this dealership to make better use of relationship quality dimensions that influence the behavioural intention of customers during their post-purchase service and repair experiences. A list of 1800 respondents was obtained from the luxury motor vehicle dealership that accurately reflects the study population.

Self-administered questionnaires were emailed to the respondents. The email consisted of a short introduction to the study, an explanation of the study's objective, the rights of respondents, the completion instructions, and a link to the actual questionnaire. Section $A$ of the questionnaire obtained the demographic information of the respondents. The aim of the 
first part of Section B was to determine the extent to which the respondents were satisfied with the dealership's post-purchase service delivery and to determine the respondents' levels of trust and commitment towards the dealership. The second part of Section $B$ assessed the levels of behavioural intention of the respondents towards the luxury motor vehicle dealership. The respondents were requested to rate statements relating to each construct on an unlabelled five-point Likert scale, where one represents "very low" and five represents "very high". The completed questionnaires were stored on a backend system hosted by Google Forms, making it easy to generate an Excel report with the answers.

Only measurement variables that had proven to be valid and reliable were considered. Customer satisfaction was measured by the scale of Dagger and O'Brien (2010)and Brady and Robertson (2001) with six measurement variables. The five measurement variables for trust and seven measurement variables for commitment were also adapted from measurement scales provided by Dagger and O'Brien (2010). Behavioural intention was measured using the scales provided by Bock, Zmud, Kim and Lee (2005), Chiou (1998), Tsaur, Lin and Wu (2005), Boyer and Hult (2006), and Hausknecht (1990), and included ten measurement variables.

The data was collected over six weeks, during which the respondents were sent regular reminders to encourage them to complete the questionnaire. A total of 301 respondents participated in the survey, resulting in a response rate of $16.27 \%$. All questionnaires returned could be used in the analysis and the realised sample falls within the minimum sample range as recommended by Hair, Black, Babin and Anderson (2010) for conducting an analysis with four constructs.

The sample was $79.4 \%$ male and $20.6 \%$ female. The majority of the respondents were either self-employed (54.2\%) or employed full-time by an organisation (32.6\%). Most of the respondents were married $(73.1 \%)$ and aged 42 years and older $(80.1 \%)$. The selected motor vehicle dealership studied sells Porsche cars to the public. Hence, all respondents who participated in the study drive a Porsche as their first vehicle of choice. Mercedes-Benz $(35.8 \%)$ and BMW (29.2\%) were among the often selected as the second vehicle driven or owned by the respondents.

The Statistical Package for the Social Sciences (SPSS) version 22 and MPlus version 7.4 were used to analyse the research data and to test the theoretical model. The data analysis included descriptive statistics, a confirmatory factor analysis (CFA) to assess the validity of the research data, Cronbach's alpha values to measure data reliability, and structural equation modelling (SEM) to test the theoretical framework. This was done according to 
Svensson's (2013) assertion that a thorough assessment of the reliability and validity or results is a critical component for contributing to theory.

\section{DATA ANALYSIS AND FINDINGS}

The validity and reliability of the data was assessed first.

\subsection{Validity and reliability}

From Table 1 it is evident that the overall mean scores for the constructs vary between 3.83 and 4.13. These scores are relatively positive, considering that all the constructs were measured on a five-point Likert scale where one represents "strongly disagree" and five represents "strongly agree".

Table 1. Descriptive statistics and covariance matrix for the latent variables with AVE on the diagonal

\begin{tabular}{|lccccc|}
\hline Variable & Mean & C1 & C2 & C3 & C4 \\
\hline C1: Customer satisfaction & 4.13 & $(0.92)$ & & & \\
C2: Trust & 4.13 & 0.90 & $(0.93)$ & & \\
C3: Commitment & 3.98 & 0.82 & 0.82 & $(0.84)$ & \\
C4: Behavioural intention & 3.83 & 0.81 & 0.79 & 0.74 & $(0.85)$ \\
\hline
\end{tabular}

Note: All correlations are significant at $p<0.05$

Face validity was achieved by using existing scales from previous studies that have been proven to be valid and reliable. The authors also reviewed the measurement items and a pilot study was undertaken to ensure that these items measure what they are intended to measure.

Discriminant validity between the four measurement constructs were confirmed by applying the tests recommended by Fornell and Larcker (1981) and Hair et al. (2010). Table 1 demonstrates that the AVE of customer satisfaction (0.92) and trust (0.93) were greater than the shared variance between them (0.90). The same conclusion was made for the AVE results of the remaining constructs. This supports the claim that customer satisfaction can be distinguished from trust, trust from commitment, and commitment from behavioural intention. Convergent validity was determined using the guidelines recommended by Hair et al. (2010), Fornell and Larcker (1981), Bagozzi and Yi (1988), and Byrne (2001). As depicted in Table 
2 , all factors were loaded onto their respective constructs $(p<0.001)$. All values (except behavioural intention statement five: "I will use social media platforms to express how satisfied I am about this dealership") were above the 0.50 cut-off value as suggested by Hair et al. (2010), which indicates acceptable loadings. However, even though the factor loading for behavioural intention statement five was low, it was not discarded as it is still significant $(p<0.001)$ and the latent variable behavioural intention explained $15 \%$ of the variance in the measurement item. All AVE values are also above 0.5 (Table 1) and the composite reliability $(\mathrm{CR})$ value for each latent variable is above the cut-off value of 0.7 (Table 2). Therefore, from these findings it can be concluded that the latent variables of customer satisfaction, trust, commitment and behavioural intention have strong reliability and convergent validity.

Construct validity was further evaluated using CFA. The measurement model for this study has good fit statistics. The chi-square/degrees of freedom $\left(\chi^{2} / \mathrm{df}\right)$ ratio was less than 5 (3.58), the Tucker-Lewis index (TLI) as well as the comparative fit index (CFI) was greater than 0.9 (0.98 in both instances). Additionally, the root mean square error of approximation (RMSEA) was less than 0.8 (0.7), providing support of an adequate model fit (Hair et al. 2010).

Table 2. Measurement model: standardised factor loadings, validity and reliability

\begin{tabular}{|c|c|c|c|c|}
\hline Construct, item & $\begin{array}{l}\text { Standardised } \\
\text { factor loadings }\end{array}$ & AVE & $\begin{array}{l}\text { Construct } \\
\text { reliability }\end{array}$ & $\begin{array}{c}\text { Cronbach's } \\
a\end{array}$ \\
\hline Customer satisfaction & & 0.92 & 0.98 & 0.98 \\
\hline $\begin{array}{l}\text { My choice to use this dealership was a wise } \\
\text { one }\end{array}$ & 0.96 & & & \\
\hline $\begin{array}{l}\text { I am always delighted with the dealership's } \\
\text { service }\end{array}$ & 0.93 & & & \\
\hline $\begin{array}{l}\text { Overall I am satisfied with the service } \\
\text { provided }\end{array}$ & 0.95 & & & \\
\hline $\begin{array}{l}\text { I did the right thing when I decided to use this } \\
\text { dealership }\end{array}$ & 0.95 & & & \\
\hline I feel good about using this dealership & 0.95 & & & \\
\hline $\begin{array}{l}\text { I feel that my experience with this dealership } \\
\text { has been enjoyable }\end{array}$ & 0.94 & & & \\
\hline Trust & & 0.93 & 0.98 & 0.98 \\
\hline This dealership can be trusted & 0.96 & & & \\
\hline $\begin{array}{l}\text { This dealership can be counted on to do what } \\
\text { is right }\end{array}$ & 0.95 & & & \\
\hline This dealership has high integrity & 0.93 & & & \\
\hline This dealership is trustworthy & 0.96 & & & \\
\hline This dealership keeps its promises & 0.95 & & & \\
\hline Commitment & & 0.84 & 0.97 & 0.98 \\
\hline $\begin{array}{l}\text { My relationship with this dealership is } \\
\text { something that I am very committed to }\end{array}$ & 0.92 & & & \\
\hline $\begin{array}{l}\text { My relationship with this dealership is very } \\
\text { important to me }\end{array}$ & 0.88 & & & \\
\hline
\end{tabular}




\begin{tabular}{|c|c|c|c|c|}
\hline Construct, item & $\begin{array}{l}\text { Standardised } \\
\text { factor loadings }\end{array}$ & AVE & $\begin{array}{l}\text { Construct } \\
\text { reliability }\end{array}$ & $\begin{array}{c}\text { Cronbach's } \\
a\end{array}$ \\
\hline $\begin{array}{l}\text { My relationship with this dealership is } \\
\text { something I really care about }\end{array}$ & 0.92 & & & \\
\hline $\begin{array}{l}\text { I believe the dealership and I are both } \\
\text { committed to the relationship }\end{array}$ & 0.97 & & & \\
\hline $\begin{array}{l}\text { I have a strong sense of loyalty to this } \\
\text { dealership }\end{array}$ & 0.94 & & & \\
\hline $\begin{array}{l}\text { This dealership is prepared to make short- } \\
\text { term sacrifices to maintain our relationship }\end{array}$ & 0.85 & & & \\
\hline $\begin{array}{l}\text { I believe the dealership and I view our } \\
\text { relationship as a long-term partnership }\end{array}$ & 0.95 & & & \\
\hline Behavioural intention & & 0.85 & 0.96 & 0.93 \\
\hline $\begin{array}{l}\text { I will share my satisfaction with this dealership } \\
\text { with friends and family }\end{array}$ & 0.92 & & & \\
\hline $\begin{array}{l}\text { I highly recommend others to make use of the } \\
\text { services provided at this dealership }\end{array}$ & 0.97 & & & \\
\hline $\begin{array}{l}\text { I will continue to bring my motor vehicle to this } \\
\text { dealership even if I had to pay more for a } \\
\text { service or a repair }\end{array}$ & 0.79 & & & \\
\hline $\begin{array}{l}\text { I will pay a higher price than competitors } \\
\text { charge for the benefits I currently receive from } \\
\text { this dealership }\end{array}$ & 0.79 & & & \\
\hline $\begin{array}{l}\text { I will use social media platforms to express } \\
\text { how satisfied I am about this dealership }\end{array}$ & 0.39 & & & \\
\hline $\begin{array}{l}\text { I will socialise at this dealership due to the } \\
\text { extra services provided by Carrera Café }\end{array}$ & 0.65 & & & \\
\hline I will defend this dealership to critics & 0.92 & & & \\
\hline I will service my car at this dealership again & 0.94 & & & \\
\hline $\begin{array}{l}\text { I will recommend this dealership's services to } \\
\text { a friend }\end{array}$ & 0.96 & & & \\
\hline $\begin{array}{l}\text { I will select the same dealership to service or } \\
\text { repair my car }\end{array}$ & 0.94 & & & \\
\hline
\end{tabular}

Note: All factors loaded significantly at $p<0.001$

All constructs measured also appear to be highly reliable as the Cronbach's alpha reliability coefficient values reported in Table 2 are all above the accepted cut-off value of 0.7 (DeVellis, 2012; Tabachnick and Fidell 2001;).

\subsection{Structural model analysis}

The research hypotheses formulated for the study were assessed using SEM to test the theoretical model proposed compared to reality (Svensson, 2015). The findings from the analysis are presented in Table 3. 
Table 3. SEM results for mediation model

\begin{tabular}{|c|c|c|c|c|}
\hline Path & $\begin{array}{c}\text { Standardised } \\
\text { effect }\end{array}$ & $\begin{array}{c}\text { Critical } \\
\text { ratio }\end{array}$ & $\begin{array}{c}p- \\
\text { value }\end{array}$ & $\begin{array}{l}\text { Hypothesis } \\
\text { support }\end{array}$ \\
\hline \multicolumn{5}{|l|}{ Direct effect } \\
\hline $\begin{array}{l}\text { H1 Customer satisfaction } \rightarrow \text { behavioural } \\
\text { intention }\end{array}$ & $0.90^{* * *}$ & 0.11 & 0.001 & Supported \\
\hline H2 Customer satisfaction $\rightarrow$ commitment & $0.50^{\star \star *}$ & 0.12 & 0.001 & Supported \\
\hline H3 Commitment $\rightarrow$ behavioural intention & $0.15^{\star *}$ & 0.05 & 0.009 & Supported \\
\hline H5 Trust $\rightarrow$ behavioural intention & -0.12 & 0.11 & 0.279 & Not supported \\
\hline H6 Trust $\rightarrow$ commitment & $0.43^{* * *}$ & 0.12 & 0.001 & Supported \\
\hline $\begin{array}{l}\text { H4 Commitment mediates the relationship } \\
\text { between customer satisfaction and behavioural } \\
\text { intention }\end{array}$ & $0.07^{*}$ & 0.03 & 0.010 & Supported \\
\hline $\begin{array}{l}H 7 \text { Commitment mediates the relationship } \\
\text { between trust and behavioural intention }\end{array}$ & 0.06 & 0.03 & 0.064 & Not supported \\
\hline \multicolumn{5}{|l|}{ Model fit statistics } \\
\hline$x^{2}$ & $1,232.106$ & & & \\
\hline df & 344 & & & \\
\hline$x^{2} / \mathrm{df}$ & 3.58 & & & \\
\hline CFI & 0.98 & & & \\
\hline TLI & 0.98 & & & \\
\hline RMSEA & 0.07 & & & \\
\hline
\end{tabular}

Notes:

Relationship is statistically significant at:

${ }^{* * *} p<0.001$

${ }^{* *} p<0.01$ and

${ }^{*} p<0.05$ 
The chi-square value obtained from the SEM analysis is significant $(X 2=1232.106$; d.f. $=344$; $p<0.05)$. However, considering the study's large sample size, the chi-square estimate may be sensitive to small model discrepancies (Bagozzi and Yi 1988; Bollen, 1989; Bollen and Long, 1993; Byrne, 1994; Jöreskog and Sörbom 1989). Therefore, the model fit statistics also had to be determined. From Table 3 it is evident that both the TLI and CFI values are greater than 0.9 - the recommended cut-off value as suggested by Bentler and Bonett (1980) and Hair et al. (2010). The ratio $\chi^{2} / \mathrm{df}$ is 3.58 , which is less than the criterion value of 5.00 and the RMSEA is less than 0.08, as recommended by Chau (1997), Steiger (1990), and Carmines and Mclver (1981). Thus, the research findings from the SEM analysis demonstrate that the model fits the observed data reasonably well.

Table 3 further indicates mostly positive standardised regression weights of the hypothesised relationships between the constructs, ranging from 0.15 to 0.90 . However, there is one exception where the standardised regression weight of the relationship between trust and behavioural intention $\left(\mathrm{H}_{5}\right)$ is negative. This suggests that $\mathrm{H}_{5}$ is rejected as it indicates that trust does not exhibit a significant and positive influence on behavioural intention when a customer has a luxury motor vehicle serviced or repaired at a luxury motor vehicle dealership. Concerning $\mathrm{H}_{1}, \mathrm{H}_{2}, \mathrm{H}_{3}$ and $\mathrm{H}_{6}$, the standardised regression weights obtained were all positive and significant, confirming that the hypothesised relationships could be accepted.

Table 3 shows that customer satisfaction has a significant positive indirect effect on behavioural intention in favour of a luxury motor vehicle dealership, as mediated by commitment towards the dealership, with $\beta$ weight $=0.07$ and $p<.05$. According to Zhao, Lynch and Chen (2010:201), if both the indirect effect and the direct effect are positive and statistically significant, the mediation can be classified as complementary mediation model (synonymous to partial mediation). Consequently, based on the results obtained from the direct effect between customer satisfaction and behavioural intention as well as the indirect effect as mediated by commitment, it can be concluded that $\mathrm{H}_{4}$ should be accepted and that complementary mediation was obtained. However, it can be seen from Table 3 that trust does not have a significant positive indirect effect on behavioural intention in favour of a luxury motor vehicle dealership, as mediated by commitment towards the dealership. The $\beta$ weight $=0.06$, but $p>.05$. Considering that the relationship between trust and behavioural intention was also not significant, it can be concluded that $\mathrm{H}_{7}$ should be rejected and that no mediating effect was evident (Zhao et al., 2010:201). 


\section{IMPLICATIONS, LIMITATIONS AND FUTURE DIRECTIONS OF THE RESEARCH}

\subsection{Theoretical implications}

From the research findings, it was evident that customer commitment in the luxury motor vehicle segment may depend on the extent to which the customer is satisfied with the service provided $\left(\mathrm{H}_{2}\right)$ and is able to trust the dealership $\left(\mathrm{H}_{6}\right)$. These findings are consistent with the work of other scholars in earlier studies (as cited in support of the relevant hypotheses formulated for the study), who identified similar relationships between customer satisfaction, trust and customer commitment. Therefore, it seems that to benefit from enduring relationships with customers who are committed and willing to invest in the dealership, it would be necessary to ensure satisfactory service is provided and that the dealership can be trusted.

Furthermore, the identified relationships between customer satisfaction, commitment and behavioural intention $\left(\mathrm{H}_{1}, \mathrm{H}_{3}\right)$ also reinforce previous findings proclaiming that customers who are pleased with the service and are committed to a longer term relationship would be willing to display behavioural intentions in favour of the service provider.

Surprisingly, no direct relationship could be found between trust and behavioural intention $\left(\mathrm{H}_{5}\right)$. These results are contradictory to scholars' earlier studies as cited in support of the relevant hypotheses formulated for the study. A possible explanation may be that within the context of a luxury motor vehicle dealership, trust serves as a cornerstone to establish a strategic partnership with the service provider in the form of commitment. The implication of this finding is that it seems in certain markets, such as the luxury motor vehicle segment, behavioural intentions are not dependent on the extent to which the customer is convinced that the service provider can be relied upon. Rather, perceptions of a reliable service offering would need to be managed to convince customers that it would be worth the maximum effort to remain committed and maintain the relationship with the service provider (Morgan and Hunt, 1994).

Considering the investigation of customer commitment as a mediating variable, it appears that the relationship between customer satisfaction and behavioural intention may be strengthened by customers' willingness to remain committed towards the service provider $\left(\mathrm{H}_{4}\right)$. These findings further support the belief that customer commitment is central to understanding consumers' behaviour in the luxury brand sector (Shukla et al., 2016) and the development of relationships with customers (Fullerton, 2005). Service providers cannot rely 
on customer satisfaction alone to generate positive behaviour in favour of the organisation (Van Vuuren, Roberts-Lombard and Van Tonder, 2012). Customer commitment is regarded as the most significant driver of customer intentions (Fullerton, 2014) and is required to strengthen relationships with customers.

Another important observation is that the research findings offer more insight into the extent to which relationship quality constructs may influence the behavioural intentions of consumers within the luxury motor vehicle segment. In relationship marketing literature, trust, commitment and customer satisfaction are regarded as fundamental constituents of relationship quality (Grönroos, 2001; Hennig-Thurau, 2000; Hennig-Thurau et al., 2002). The structural model presented in this study reinforces the importance of these constructs in relation to the post-purchase service offered by a luxury motor vehicle dealership, sheds more light on the interrelationships between them, and indicates how they may affect behavioural intention. Therefore, current research aids in augmenting the understanding of the practice of relationship quality within the luxury motor vehicle segment and the extent to which the presence of all three constructs are required to benefit from relationship quality.

\subsection{Managerial implications}

To promote favourable behavioural intentions, it would be imperative for the luxury motor vehicle dealerships to enhance relationship quality. The dealership first needs to ensure that the post-purchase service and repairs offered to owners are of such standards that customers will be satisfied. Therefore, a luxury motor vehicle dealership should assess its customer satisfaction levels continuously by comparing customers' experience with their service expectations when they take their luxury motor vehicles for a service or repairs. Customer satisfaction can be assessed by hiring and/or training employees capable of asking customers for feedback. The luxury motor vehicle dealership can identify areas where customer satisfaction levels are low, and marketing strategies can be crafted and implemented to improve customer satisfaction in these areas.

Luxury motor vehicle dealerships should ensure that the service is consistent in the way employees handle queries, in the language used to interact with customers, and in how issues are escalated to management level. Customers should feel comfortable, proud and positive about choosing the dealership to service or repair their luxury motor vehicles. This requires a luxury motor vehicle dealership to provide adequate training to frontline employees and managers. The dealership also needs to enhance owners' trust by promoting the dealership's trustworthiness. Luxury motor vehicle dealerships should be honest with 
customers who bring their luxury motor vehicles for a service or repairs. It is critical for luxury motor vehicle dealerships never to over-promise and under-deliver, as customers will test the promises made by the dealership. Only if customers find that the luxury motor vehicle dealership fulfils or exceeds its promises will they be willing to contribute to building a relationship with the dealership.

Furthermore, luxury motor vehicle dealerships should facilitate the complaint process and provide adequate feedback. Customers should be provided with phone numbers, email addresses and other ways to inform the dealership when there is a problem. It is also vital for a luxury motor vehicle dealership to measure the trust levels of customers in relation to customer service and the dealership. Lastly, for a luxury motor vehicle dealership to improve its customers' level of commitment, the dealership needs to convey professionalism by being confident and knowledgeable, and by displaying organisational pride through its actions and appearance. A luxury motor vehicle dealership should also prove to customers that it sincerely cares about their concerns while working quickly and efficiently to resolve any issues customers might have.

\subsection{Limitations and directions for further research}

The research findings are based on the responses obtained from one luxury motor vehicle dealership in the Gauteng province, and the results cannot be generalised to other geographical regions. Typical South African customers base their decisions and actions on their cultural background, and because South Africa is a diverse country, it would be difficult to accurately predict the behaviour of the larger population. Therefore, it is recommended that the same study be repeated on a larger scale, to obtain more insight into the perceptions of luxury motor vehicle owners in other regions of the country.

The relationship quality and behavioural intention constructs investigated in this study further relate to long-term measurements. In future studies, it would be preferable to examine longitudinal data to determine the extent to which the interrelationships of the constructs investigated in this study may be different. A comparative study could also be conducted to investigate the influence of relationship quality factors on behavioural intention towards luxury motor vehicle dealerships and the more affordable motor vehicle dealerships. It would be interesting to determine whether statistically significant differences exist between the different types of dealerships. However, despite the limitations mentioned in this section, the present study should be viewed as a step towards addressing the gap in marketing research 
relating to the South African luxury motor vehicle segment and may serve as the foundation for further research on this topic. 


\section{REFERENCES}

Amin, M. and Nasharuddin, S.Z. (2013), "Hospital service quality and its effects on patient satisfaction and behavioural intention", Clinical Governance: An International Journal, Vol. 18 No. 3, pp. 238-254.

Anderson, J.C. and Narus, J.A. (1990), "A model of distributor firm and manufacturer firm working partnerships", Journal of Marketing, Vol. 54 No. 1, pp. 42-58.

Athanasopoulou, P. (2009), "Relationship quality: a critical literature review and research agenda", European Journal of Marketing, Vol. 43 Nos. 5/6, pp. 583-610.

Bagozzi, R.P. and Yi, Y. (1988), "On the evaluation of structural equation models", Academy of Marketing Science, Vol 6 No. 1, pp. 74-93.

Becerra, E.P. and Korgaonkar, P.K. (2011), "Effects of trust beliefs on consumers' online intentions", European Journal of Marketing, Vol. 45 No. 6, pp. 936-962.

Bentler, P.M and Bonett, D.G. (1980), "Significance tests and goodness of fit in the analysis of covariance structures", Psychological Bulletin. Vol. 88 No. 3, p. 588.

Berry, L.L. (1995), "Relationship marketing of services - growing interest, emerging perspectives", Journal of the Academy of Marketing Science, Vol. 23 No. 4, pp. 236-245.

Bock, G., Zmud, R.W., Kim, Y.G. and Lee, J.N. (2005), "Behavioural intention formation in knowledge sharing: examining the roles of extrinsic motivators, social-psychological forces, and organizational climate", MIS Quarterly, Vol. 29 No. 1, pp. 87-111.

Bollen, K.A. (1989), Structural Equations with Latent Variables. Wiley, New York, NY.

Bollen, K.A. and Long, J.S. (1993), Testing Structural Equation Models, Sage, Newbury Park, CA.

Boyer, K.K. and Hult, G.T.M. (2006), "Customer behavioral intentions for online purchases: an examination of fulfilment method and customer experience level", Journal of Operations Management, Vol. 26 No. 1, pp. 124-147. 
Brady, M.K. and Robertson, C.J. (2001), "Searching for a consensus on the antecedent role of service quality and satisfaction: an exploratory cross-national study", Journal of Business Research, Vol. 51 No. 1, pp. 53-60.

Byrne, B.M. (1994), Structural Equation Modeling with EQS and EQS/Windows: Basic Concepts, Applications, and Programming, Sage, Thousand Oaks, CA.

Byrne, B.M. (2001), Structural Equation Modeling with AMOS: Basic Concepts, Applications and Programming, Lawrence Erlbaum Associates, Mahwah, NJ.

Carmines, E. and Mclver, J. (1981), "Analyzing models with unobserved variables: analysis of covariance structures", in Bohrnstedt, G. and Borgatta, E. (Eds), Social Measurement: Current Issues Sage, Beverly Hills, CA, pp. 65-115.

Casielles, R.V., Álvarez, L.S. and Martin, A.M.D. (2005), "Trust as a key factor in successful relationships between consumers and retail service providers", The Service Industries Journal, Vol. 25 No. 1, pp. 83-101.

Chandon, J.L., Laurent, G. and Valette-Florence, P. (2015), "Pursuing the concept of luxury: introduction to the JBR Special Issue on 'Luxury Marketing from Tradition to Innovation"', Journal of Business Research, Vol. 69 No. 1, pp. 299-303.

Chau, P.Y.K. (1997), "Reexamining a model for evaluating information center success using a structural equation modeling approach", Decision Sciences, Vol. 28 No. 2, pp. 309-334.

Chiou, J. (1998), "The effects of attitude, subjective norm, and perceived behavioral control on consumers' purchase intentions: the moderating effects of product knowledge and attention to social comparison information", Proceedings of the National Science Council, Vol. 9 No. 2, pp. 298-308.

Choo, H.J., Moon, H., Kim, H. and Yoon, N. (2012), "Luxury customer value", Journal of Fashion Marketing and Management: An International Journal, Vol. 16 No. 1, pp. 81-101.

Cronin, J.J., Brady, M.K. and Hult, G.T.M. (2000), "Assessing the effects of quality, value, and customer satisfaction on consumer behavioral intentions in service environments", Journal of Retailing, Vol. 76 No. 2, pp. 193-218. 
Crosby, L.A., Evans, K.R. and Cowles, D. (1990), "Relationship quality in services selling: an interpersonal influence perspective", Journal of Marketing, Vol. 54 No. 3, pp. 68-82.

Dagger, T.S. and O'Brien, T.K. (2010), “Does experience matter? Differences in relationship benefits, satisfaction, trust, commitment and loyalty for novice and experienced service users", European Journal of Marketing, Vol. 44 No. 9, pp. 1528-1552.

De Wulf, K., Odekerken-Schröder, G. and lacobucci, D. (2001), "Investments in consumer relationships: a cross-country and cross-industry exploration”, Journal of Marketing, Vol. 65, October, pp. 33-50.

De Wulf, K., Odekerken-Schröder, G. and Van Kenhove, P. (2003), "Investments in consumer relationships: a critical reassessment and model extension”, The International Review of Retail, Distribution and Consumer Research, Vol. 13 No. 3, pp. 245-61.

DeVellis, R.F. (2012), Scale Development: Theory and Applications, 3rd ed, Sage, Thousand Oaks, CA.

Dimitriades, Z.S. (2006), "Customer satisfaction, loyalty and commitment in service organizations", Management Research News, Vol. 29 No. 12, pp. 782-800.

Farrelly, J.F. and Quester, G.P. (2005), "Examining important relationships quality constructs of the focal sponsorship exchange", Industrial Marketing Management, Vol. 34 No. 3, pp. 211-219.

Fin24. (2016), "Supercars for the super-rich", available at: http://www.fin24.com/Finweek/Personal-finance/supercars-for-the-super-rich-20160120 (accessed 17 August 2016).

Forgas-Coll, S., Palau-Saumell, R., Sánchez-García, J. and Caplliure-Giner, E.M. (2014), "The role of trust in cruise passenger behavioral intentions: the moderating effects of the cruise line brand", Management Decision, Vol. 52 No. 8, pp. 1346-1367.

Fornell, C. and Larcker, D.F. (1981), "Evaluating structural equation models with unobservable variables and measurement error", Journal of Marketing Research, Vol. 18 No. 1 , pp. 39-50. 
Fullerton, G. (2005), "How commitment both enables and undermines marketing relationships", European Journal of Marketing, Vol. 39 Nos. 11/12, pp. 1372-1388.

Fullerton, G. (2014), "The moderating effect of normative commitment on the service qualitycustomer retention relationship". European Journal of Marketing, Vol. 48 No. 3/4, pp. 657673.

Giovanis, A., Athanasopoulou, P. and Tsoukatos, E. (2015), "The role of service fairness in the service quality - relationship quality - customer loyalty chain: an empirical study", Journal of Service Theory and Practice, Vol. 25 No. 6, pp. 744-776.

Grönroos, C. (2001), Service Management and Marketing: A Customer Relationship Management Approach, 2nd ed., Wiley, New York, NY.

Hair, J.F, Black, W.C., Babin, B.J. and Anderson, R.E. (2010), Multivariate Data Analysis, Prentice Hall, Upper Saddle River, NJ.

Hausknecht, D.R. (1990), "Measurement scales in consumer satisfaction/dissatisfaction", Journal of Customer Satisfaction, Dissatisfaction \& Complaining Behavior, Vol. 3 No. 1, pp. $1-11$.

Hennig-Thurau, T. (2000), "Relationship quality and customer retention through strategic communication of customer skills", Journal of Marketing Management, Vol. 16 Nos. 1-3, pp. $55-79$.

Hennig-Thurau, T., Gwinner, P.K. and Gremler, D.D. (2002), "Understanding relationship marketing outcomes. an integration of relational benefits and relationship quality", Journal of Service Research, Vol. 4 No. 3, pp. 230-47.

Henry, J. (2012), "The surprising ways car dealers make the most money off you", available at: http://www.forbes.com/sites/jimhenry/2012/02/29/the-surprising-ways-car-dealers-makethe-most-money-off-of-you/ (accessed 29 September 2015).

Herington, C., Johnson, L.W. and Scott, D. (2006), “Internal relationships", European Business Review, Vol. 18 No. 5, pp. 364-381. 
Hess, J. and Story, J. (2005), "Trust-based commitment: multidimensional consumer-brand relationships", Journal of Consumer Marketing, Vol. 22 No 6, pp. 313-322.

Hunt, S.D., Arnett, D.B. and Madhavaram, S. (2006), "The explanatory foundations of relationship marketing theory", Journal of Business \& Industrial Marketing, Vol. 21 No. 2, pp. 72-87.

Jaiswal, A.K. and Niraj, R. (2011), "Examining mediating role of attitudinal loyalty and nonlinear effects in satisfaction-behavioral intentions relationship", Journal of Services Marketing, Vol. 25 No. 3, pp. 165-175.

Jani, D. and Han, H. (2011), "Investigating the key factors affecting behavioral intentions: evidence from a full-service restaurant setting", International Journal of Contemporary Hospitality Management, Vol. 23 No. 7, pp. 1000-1018.

Johnson, M.D. and Fornell, C. (1991), "A framework for comparing customer satisfaction across individuals and product categories", Journal of Economic Psychology, Vol. 12 No. 2, pp. 267-286.

Johnson, M.S., Sivadas, E. and Garbarino, E. (2008), "Customer satisfaction, perceived risk and affective commitment: an investigation of directions of influence", Journal of Services Marketing, Vol. 22 No. 5, pp. 353-362.

Jones, T., Fox, G.L., Taylor, S.F. and Fabrigar, L.R. (2010), "Service customer commitment and response", Journal of Services Marketing, Vol. 24 No. 1, pp. 16-28.

Jöreskog, K.G. and Sörbom, D. (1989), LISREL VII: User's Reference Guide, Scientific Software, Chicago, IL.

Kansperger, R. and Kunz, W.H. (2010), "Consumer trust in service companies: a multiple mediating analysis", Managing Service Quality, Vol. 20 No. 1, pp. 4-25.

Kapferer, J.N. and Valette-Florence, P. (2016), "Beyond rarity: the paths of luxury desire. How luxury brands grow yet remain desirable", Journal of Product \& Brand Management, Vol. 25 No. 2, pp. 120-133. 
Khojastehpour, M. and Johns, R. (2014), "Internationalization and relationship marketing: an introduction", European Business Review, Vol. 26 No. 3, pp. 238-253.

Lang, B. and Colgate, M. (2003), "Relationship quality, on-line banking and the information technology gap", International Journal of Bank Marketing, Vol. 21 No. 1, pp. 29-37.

Liang, C.J. and Wang, W.H. (2007), "An insight into the impact of a retailer's relationship efforts on customers' attitudes and behavioral intentions", International Journal of Bank Marketing, Vol. 25 No. 5, pp. 336-366.

Liang, R.D and Zhang, J.S. (2012), "The effect of service interaction orientation on customer satisfaction and behavioral intention: the moderating effect of dining frequency", Asia Pacific Journal of Marketing and Logistics, Vol. 4 No. 1, pp. 153-170.

Limbu, Y.B., Wolf, M. and Lunsford, D. (2012), "Perceived ethics of online retailers and consumer behavioral intentions", Journal of Research in Interactive Marketing, Vol. 6 No. 2, pp. 133-154.

Lin, C. and Ding, G.C. (2005), "Opening the black box: assessing the mediating mechanism of relationship quality and the moderating effects of prior experience in ISP service", International Journal of Service Industry Management, Vol. 16 No. 1, pp. 55-80.

Macintosh, G. (2007), "Customer orientation, relationship quality, and relational benefits to the firm", Journal of Services Marketing, Vol. 21 No. 3, pp. 150-159.

Martin, D., O'Neill, M., Hubbard, S. and Palmer, A. (2008), "The role of emotion in explaining consumer satisfaction and future behavioural intention", Journal of Services Marketing, Vol. 22 No. 3, pp. 224-236.

McCole, P. (2004), "Refocusing marketing to reflect practice: the changing role of marketing for business", Marketing Intelligence \& Planning, Vol. 22 No. 5, pp. 531-539.

McCollough, M.A., Berry, L.L. and Yadav, M.S. (2000), "An empirical investigation of customer satisfaction after service failure and recovery", Journal of Service Research, Vol. 3 No. 2, pp. 121-37. 
Moliner, M.A., Sánchez, J., Rodríguez, M.R. and Callarisa, L. (2007a), "Relationship quality with a travel agency: the influence of the postpurchase perceived value of a tourism package", Tourism and Hospitality Research, Vol. 7 Nos. 3/4, pp. 194-211.

Moliner, M.A., Sánchez, J., Rodríguez, R.M. and Callarisa, L. (2007b), “Perceived relationship quality and post-purchase perceived value: an integrative framework", European Journal of Marketing, Vol. 41 Nos. 11/12, pp. 1392-1422.

Moreira, A.C. and Silva, P.M. (2015), "The trust-commitment challenge in service qualityloyalty relationships", International Journal of Health Care Quality Assurance, Vol. 28 No. 3, pp. 253-266.

Morgan, R.M. and Hunt, S.D. (1994), "The commitment-trust theory of relationship marketing", Journal of Marketing, Vol. 58 No. 3, pp. 20-38.

NAAMSA. (2016), "Passenger market - July 2016", available at: http://www.naamsa.co.za/flash/pas.html (accessed 17 August 2016).

Ou, W.M., Shih, C.M., Chen, C.Y. and Wang, K.C. (2011), "Relationships among customer loyalty programs, service quality, relationship quality and loyalty: an empirical study", Chinese Management Studies, Vol. 5 No. 2, pp. 194-206.

Parasuraman, A., Berry, L.L. and Zeithaml, V.A. (1994), "Reassessment of expectations as a comparison standard in measuring service quality: implications for further research", Journal of Marketing, Vol. 58 No. 1, pp. 111-24.

Qin, H. and Prybutok, V.R. (2009), "Service quality, customer satisfaction, and behavioral intentions in fast-food restaurants", International Journal of Quality and Service Sciences, Vol. 1 No. 1, pp. 78-95.

Roberts, K., Varki, S. and Brodie, R. (2003), "Measuring the quality of relationships in consumer services: an empirical study", European Journal of Marketing, Vol. 37 Nos 1/2, pp. 169-196.

Shaw, E. (2014), "The quest for a general theory of the marketing system", Journal of Historical Research in Marketing, Vol. 6 No. 4, pp. 523-537. 
Shukla, P., Banerjee, M. and Singh, J. (2016), "Customer commitment to luxury brands: antecedents and consequences", Journal of Business Research, Vol. 69 No. 1, pp. 323-331.

Southey, G. (2011), "The theories of reasoned action and planned behaviour applied to business decisions: a selective annotated bibliography", Journal of New Business Ideas \& Trends, Vol. 9 No. 1, pp. 43-50, available at: www.jnbit.org/upload/JNBIT_Southey_2011_1.pdf (accessed 15 August 2016).

Stavros, C. and Westberg, K. (2009), "Using triangulation and multiple case studies to advance relationship marketing theory", Qualitative Market Research: An International Journal, Vol. 12 No. 3, pp. 307-320.

Steiger, J.H. (1990), "Structural model evaluation and modification: an interval estimation approach”, Multivariate Behavioral Research, Vol. 25 No. 2, pp. 173-180.

Storbacka, K., Strandvik, T. and Grönroos, C. (1994), "Managing customer relationships for profit: the dynamics of relationship quality", International Journal of Service Industry Management, Vol. 5 No. 5, pp. 21-38.

Sumaedi, S. Juniarti, R.P. and Bakti, G.M.Y. (2015), "Understanding trust \& commitment of individual saving customers in Islamic banking: the role of ego involvement", Journal of Islamic Marketing, Vol. 6 No. 3, pp. 406-428.

Svensson, G. (2013), "Processes of substantiations and contributions through theory building towards theory in business research", European Business Review, Vol. 25 No. 5, pp. 466-480.

Svensson, G. (2015), "Contemporary process to test the theory of a research model through covariance-based structural equation modeling in business research", European Business Review, Vol. 27 No. 4, pp. 447-458.

Tabachnick, B.G. and Fidell, L.S. (2001), Using Multivariate Statistics, 4th ed, Harper \& Row, New York, NY.

Tsaur, S., Lin, C. and Wu, C. (2005), "Cultural differences of service quality and behavioral intention in tourist hotels", Journal of Hospitality \& Leisure Marketing, Vol. 13 No. 1, pp. 4163. 
Ural, T. (2009), "The effects of relationship quality on export performance: a classification of small and medium-sized Turkish exporting firms operating in single export-market ventures", European Journal of Marketing, Vol. 43 Nos. 1/2, pp. 139-168.

Van Vuuren, T., Roberts-Lombard, M. and Van Tonder, E. (2012), "Customer satisfaction, trust and commitment as predictors of customer loyalty within an optometric practice environment", Southern African Business Review, Vol. 16 No. 3, pp. 81-96.

Vesel, P. and Zabkar, V. (2010), "Comprehension of relationship quality in the retail environment”, Managing Service Quality: An International Journal, Vol. 20 No. 3, pp. 213235.

Vieira, A.L. (2013), "Assessing relationship quality and its key constructs from a rival models approach", Management Research: Journal of the Iberoamerican Academy of Management, Vol. 11 No. 2, pp. 113-132.

Vranesevic, T., Vignali, C. and Vignali, D. (2002), "Culture in defining consumer satisfaction in marketing", European Business Review, Vol. 14 No. 5, pp. 364-374.

Zeithaml, V.A. and Bitner, M.J. (2000), Services Marketing: Integrating Customer Focus across the Firm, McGraw-Hill, New York, NY.

Zhao, X., Lynch, J.G. and Chen, Q. (2010), "Reconsidering Baron and Kenny: myths and truths about mediation analysis", Journal of Consumer Research, Vol. 37 No. 2, pp. 197-206. 